Vol. 6 (1997): 11-18.

\title{
Estimates of genetic parameters of trotting performance traits for repeated annual records
}

\author{
Jukka Pösö \\ Agricultural Research Centre of Finland, Institute of Animal Production, FIN-31600 Jokioinen, Finland. \\ e-mail: jukka.poso@mtt.fi \\ Matti Ojala \\ Department of Animal Science, P.O. Box 28, FIN-00014 University of Helsinki, Finland.
}

\begin{abstract}
The heritability and repeatability of trotting performance traits and genetic and phenotypic correlations among these traits were estimated from repeated annual records of 6934 Finnhorse and 5298 Standardbred trotters. The number of observations in the two breeds was 19550 and 14184 , respectively. (Co)variance components were obtained with animal model and restricted maximum likelihood (REML) method. The heritability estimates were highest for time traits $(0.29$ to 0.35$)$ and lowest for number of starts $(0.08$ to 0.10$)$ in the two breeds. The repeatability estimates were high for time traits but only moderate for other trotting performance traits, suggesting that repeated records improve accuracy in genetic evaluations. The genetic correlations among the performance traits, especially between time and money traits, were very high and favourable considering the breeding goals. The phenotypic associations were distinctly weaker than the genetic ones.
\end{abstract}

Key words: Finnhorse, Standardbred trotter, animal model, REML

\section{Introduction}

In many countries, the breeding value of the trotting performance traits of horses is estimated from annually summarized racing records. Annual records may be utilized for individual age classes separately or they can be pooled over age classes to form career records. Because the heritability estimates are higher than those of individual age classes (Pösö 1993, Pösö et al. 1994) early career records seem to provide a more ap- propriate approach for genetic evaluations. The heritability estimates for early career records, e.g., annual records summarized over the first three age groups, are, however, likely to be overestimated at least under Finnish conditions. There are two main reasons for this: first, the variation between animals is bound to be large due to selection after one or two years of racing. Around 15\% of the Finnhorses born in 1975 to 1984 and taking part in trotting races raced during one season only and about $27 \%$ during two seasons (Pösö 1993). The corresponding percent- 


\section{AGRICULTURAL AND FOOD SCIENCE IN FINLAND}

\section{Pösö, J. \& Ojala, M. Estimates of genetic parameters of trotting performance traits}

ages among Standardbred trotters born in 1981 to 1985 were about $15 \%$ and $25 \%$, respectively. The poorest performers are likely to be culled after one or two years of racing, only the better ones being given an opportunity to race long enough to have a full career. Thus, for inferior horses the early career may, at worst, comprise records from one age class only whereas superior horses may have records from all age classes. Second, incomplete career results, i.e., the careers of horses without a record in every age class, consist of annually summarized racing records done in different time spans and at different ages (Saastamoinen and Ojala 1994). Thus, the variation caused by age and racing year is confounded by the additive genetic effect when the estimated breeding values are based on career records.

On the other hand, the effects of age and racing year could be accounted for if the annual records were taken as repeated measurements of the same traits. Estimates of genetic correlations between the same traits in different age classes have been high (Langlois 1984, Pylvänäinen 1987, Arnason et al. 1989, Pösö 1993), suggesting that the performance traits are the same traits at different stages of a career, and thus allowing use of the repeatability model. Moreover, the reported genetic correlations among trotting performance traits have been rather stabile at different ages (Pylvänäinen 1987, Arnason et al. 1989).

The repeatability model would treat more fairly those horses that do not have records from several years in the database. Such a situation might arise if a horse were, say, injured or lamed in an accident, or were imported or exported, thus resulting in an incomplete career length. The estimates of repeatability for annual trotting performance records have been reported to be fairly high for time traits and moderate for other traits (Pylvänäinen 1987, Arnason 1989, Saastamoinen and Ojala 1991, Pösö 1993).

Heritability estimates for repeated annual records of trotting performance traits have been reported in some studies (Tavernier 1989, Saastamoinen and Ojala 1991, Pösö 1993, Pösö et al. 1994). If, however, repeated annual records are to be utilized for multitrait breeding value estimation, the genetic and phenotypic correlations among the traits should be available in addition to the estimates of heritability and repeatability for the different traits. The purpose of this study then was to estimate genetic and phenotypic parameters for trotting performance traits with the animal model and restricted maximum likelihood (REML) method using repeated annual records of Finnhorse and Standardbred trotters.

\section{Material and methods}

\section{Data}

The data consisted of the annually summarized racing records for Finnhorse trotters born in 1975 to 1984 , and for Standardbred trotters born in 1981 to 1985 . A horse was included in the data set if it had a record in any of the four different age classes $(\leq 4,5,6$ or 7 for Finnhorses; $\leq 3,4$, 5 or 6 for Standardbred trotters). After these edits the number of Finnhorse trotters in the data set was 6934 with 19550 observations. The data set for Standardbred trotters included both Finnish born (4127 horses) and imported horses (1171 horses) resulting altogether in $\mathbf{5 2 9 8}$ horses with 14184 observations. Finnhorse trotters had 547 sires (with an average of 9.8 offspring per sire) and 3770 dams, and Standardbred trotters 543 sires (12.7 offspring per sire on average) and 3455 dams.

The traits studied were those that are either currently used in the Finnish breeding value estimation system or are otherwise commonly used in horse breeding: the best time in both voltstart and autostart, fourth root transformation of total earnings and earnings per start, number of starts, and logit transformation of number of first placings (wins), number of first to third placings, number of disqualified races and number of races where a horse had broken stride. A more de- 


\section{AGRICULTURAL AND FOOD SCIENCE IN FINLAND}

Vol. 6 (1997): 11-18.

tailed description of the traits and a discussion of the effects of different transformations on some of the traits have been by Ojala (1987) and Pylvänäinen (1987). The logit transformation was performed according to Snedecor and Cochran (1967):

$\mathrm{y}=\ln [(\mathrm{g}+0.5) /(\mathrm{n}-\mathrm{g}+0.5)]$

where $y$ is the logit transformation of number of first placings, number of first to third placings, number of disqualified races or number of races where a horse had broken stride; $g$ is the number of incidences of interest; and $\mathrm{n}$ is the total number of races in which a horse has participated.

\section{Statistical methods}

Estimates of heritability and repeatability were obtained from univariate analyses. Owing to computational limitations only two traits could be analysed simultaneously for the estimates of genetic and phenotypic correlations. The two breeds were studied separately. During the bivariate analyses the following linear animal model was assumed:

$$
\left[\begin{array}{l}
y_{1} \\
y_{2}
\end{array}\right]=\left[\begin{array}{ll}
x_{1} & 0 \\
0 & x_{2}
\end{array}\right]\left[\begin{array}{l}
b_{1} \\
b_{2}
\end{array}\right]+\left[\begin{array}{ll}
z_{p 1} & 0 \\
0 & z_{p 2}
\end{array}\right]\left[\begin{array}{l}
p_{1} \\
p_{2}
\end{array}\right]+\left[\begin{array}{ll}
z_{a 1} & 0 \\
0 & z_{a 2}
\end{array}\right]\left[\begin{array}{l}
a_{1} \\
a_{2}
\end{array}\right]+\left[\begin{array}{l}
e_{1} \\
e_{2}
\end{array}\right]
$$

where $\mathbf{y}_{i}$ is the vector of records on one of the trotting performance traits, $\mathbf{b}_{i}$ is the vector of fixed effects including birth year (10 classes for Finnhorses, 5 classes for Standardbred trotters), sex (2 classes) and age at racing year (4 classes), $\mathbf{p}_{i}$ is the vector of permanent environment, $\mathbf{a}_{\mathrm{i}}$ is the vector of breeding values, $\mathbf{e}_{\mathrm{i}}$ is the vector of residual effects, and $\mathbf{X}_{\mathrm{i}}, \mathbf{Z}_{\mathrm{pi}}$ and $\mathbf{Z}_{\mathrm{ai}}$ are the incidence matrices that link the effects to $\mathbf{y}_{i}$. In the analysis of the data set for Standardbred trotters, the statistical model included also the fixed effect of country of birth with two classes: Finnish born and imported horses. This was done to account for the effect of selection due to Finnish import regulations.

The effects of $\mathbf{p}$, a and $\mathbf{e}$ were assumed random with zero means and $\operatorname{var}(\mathbf{p})=\mathbf{P}_{0} \otimes \mathbf{I}$, $\operatorname{var}(\mathbf{a})=\mathbf{G}_{0} \otimes \mathbf{A}$ and $\operatorname{var}(\mathbf{e})=\mathbf{R}_{0} \otimes \mathbf{I}$, where $\mathbf{I}$ is the identity matrix; $\mathbf{A}$ is a matrix of additive relationships among animals; $\mathbf{P}_{0}, \mathbf{G}_{0}$ and $\mathbf{R}_{0}$ are the $2 \times 2$ variance-covariance matrices for the permanent environment, additive genetic and residual effects, respectively, and $\otimes$ denotes a kronecker product. The covariances between $\mathbf{p}$, a and $\mathbf{e}$ were assumed zero.

The additive relationship matrix contained all known relatives that contributed to the (co)variance components. For Finnhorse trotters the number of pedigree animals (i.e., animals that were included in the additive relationship matrix but did not have a record) was 15732 and for Standardbred trotters 12 750. The (co)variance components were estimated with the DMU program package (Jensen and Madsen 1994) using the REML method and AI-REML algorithm based on the average of the observed and expected information matrix (Johnson and Thompson 1995), which also gives the sampling variances for the estimates.

\section{Results and discussion}

\section{Heritability and repeatability}

The heritability and repeatability estimates for trotting performance traits and sampling errors for heritability are presented in Table 1 for Finnhorse and in Table 2 for Standardbred trotters. The estimates were very similar for the two breeds. The highest heritability estimates were obtained for time and money traits, where as the 


\section{AGRICULTURAL AND FOOD SCIENCE IN FINLAND}

Pösö, J. \& Ojala, M. Estimates of genetic parameters of trotting performance traits

Table 1. Estimates of variance components, heritability $\left(\mathrm{h}^{2}\right)$ and repeatability $(r)$ for trotting performance traits of Finnhorse trotters.

\begin{tabular}{lccccc}
\hline Trait & $\begin{array}{c}\text { additive } \\
\text { genetic }\end{array}$ & $\begin{array}{c}\text { permanent } \\
\text { environment }\end{array}$ & $\begin{array}{c}\text { residual } \\
\text { variance }\end{array}$ & $h^{2} \pm s . e$. & $0.35 \pm 0.02$ \\
\hline VO & 21.079 & 24.678 & 14.003 & 0.77 \\
AU & 17.354 & 18.164 & 14.066 & $0.35 \pm 0.02$ & 0.72 \\
EA & 3.159 & 3.958 & 8.239 & $0.21 \pm 0.02$ & 0.46 \\
ES & 0.723 & 0.701 & 1.630 & $0.24 \pm 0.02$ & 0.47 \\
WI & 0.112 & 0.143 & 0.627 & $0.13 \pm 0.01$ & 0.29 \\
PL & 0.231 & 0.141 & 0.684 & $0.22 \pm 0.01$ & 0.35 \\
BR & 0.136 & 0.182 & 0.664 & $0.14 \pm 0.02$ & 0.32 \\
DI & 0.165 & 0.327 & 0.875 & $0.12 \pm 0.01$ & 0.36 \\
ST & 8.083 & 21.168 & 51.747 & $0.10 \pm 0.01$ & 0.36 \\
\hline
\end{tabular}

s.e. $=$ standard error

$\mathrm{VO}=$ best time in voltstart, $\mathrm{AU}=$ best time in autostart, $\mathrm{EA}=(\text { total earnings })^{1 / 4}, \mathrm{ES}=(\text { earnings/start })^{1 / 4}$, WI $=$ logit $($ number of first placings), $\mathrm{PL}=$ logit (number of first to third placings), $\mathrm{BR}=\log$ it (number of races breaking stride), $\mathrm{DI}=\mathrm{logit}$ (number of disqualified races), ST=number of starts

Table 2. Estimates of variance components, heritability $\left(\mathrm{h}^{2}\right)$ and repeatability $(\mathrm{r})$ for trotting performance traits of Standardbred trotters.

\begin{tabular}{lccccc}
\hline Trait & $\begin{array}{c}\text { additive } \\
\text { genetic }\end{array}$ & $\begin{array}{c}\text { permanent } \\
\text { environment }\end{array}$ & $\begin{array}{r}\text { residual } \\
\text { variance }\end{array}$ & $h^{2} \pm s . e$. & $0.35 \pm 0.03$ \\
VO & 3.689 & 2.728 & 4.044 & 0.61 \\
AU & 2.627 & 2.645 & 3.884 & $0.29 \pm 0.02$ & 0.58 \\
EA & 4.345 & 3.405 & 10.529 & $0.24 \pm 0.02$ & 0.42 \\
ES & 1.090 & 0.520 & 2.069 & $0.30 \pm 0.02$ & 0.44 \\
WI & 0.102 & 0.138 & 0.625 & $0.12 \pm 0.01$ & 0.28 \\
PL & 0.192 & 0.120 & 0.697 & $0.19 \pm 0.02$ & 0.31 \\
BR & 0.160 & 0.249 & 0.730 & $0.14 \pm 0.02$ & 0.36 \\
DI & 0.161 & 0.397 & 0.882 & $0.11 \pm 0.01$ & 0.39 \\
ST & 6.706 & 19.573 & 56.662 & $0.08 \pm 0.01$ & 0.32 \\
\hline
\end{tabular}

s.e. $=$ standard error

$\mathrm{VO}=$ best time in voltstart, $\mathrm{AU}=$ best time in autostart, $\mathrm{EA}=(\text { total earnings })^{1 / 4}, \mathrm{ES}=(\text { earnings/start })^{1 / 4}, \mathrm{WI}=$ logit $(\mathrm{number}$ of first placings), $\mathrm{PL}=\operatorname{logit}$ (number of first to third placings), $\mathrm{BR}=\operatorname{logit}$ (number of races breaking stride), $\mathrm{DI}=\operatorname{logit}$ (number disqualified races), ST=number of starts

largest unexplained variation was found for number of starts. The heritability estimates were almost the same as those obtained from the data in which the horses had one additional age class record covering the latter part of their career (Pösö 1993). The estimates agree well with previous ones obtained from repeated annual records. Tavernier (1989) reported a heritability of 0.26 for earnings per start estimated from records of five age classes. The estimates of
Saastamoinen and Ojala (1991) for Standardbred Trotters were similar in magnitude to those obtained here, but for some reason the heritability estimates for Finnhorse trotters were close to zero. The records were from the first three age classes.

The estimated repeatabilities were high for time traits and moderate, ranging from 0.28 to 0.47 , for other traits. This implies that the accuracy of estimated breeding values could be im- 


\section{AGRICULTURAL AND FOOD SCIENCE IN FINLAND}

Vol. 6 (1997): 11-18.

Table 3. Estimates of genetic (above diagonal) and phenotypic (below diagonal) correlations, and standard errors for the genetic correlations (in parentheses) of performance traits for Finnhorse trotters.

\begin{tabular}{lccccccccc}
\hline Trait & VO & AU & EA & ES & WI & PL & BR & DI & ST \\
\hline VO & - & 1.0 & -0.98 & -0.97 & -0.48 & -0.82 & 0.71 & 0.57 & -0.87 \\
& & $(0.00)$ & $(0.00)$ & $(0.01)$ & $(0.06)$ & $(0.03)$ & $(0.04)$ & $(0.04)$ & $(0.02)$ \\
AU & 0.91 & - & -0.97 & -0.97 & -0.68 & -0.89 & 0.71 & 0.03 & -0.74 \\
& & & $(0.01)$ & $(0.01)$ & $(0.05)$ & $(0.02)$ & $(0.05)$ & $(0.05)$ & $(0.04)$ \\
EA & -0.82 & -0.76 & - & 0.99 & 0.59 & 0.89 & -0.58 & -0.52 & 0.82 \\
& & & & $(0.00)$ & $(0.06)$ & $(0.02)$ & $(0.06)$ & $(0.05)$ & $(0.02)$ \\
ES & -0.77 & -0.73 & 0.94 & - & 0.70 & 0.94 & -0.57 & -0.51 & 0.73 \\
& & & & & $(0.05)$ & $(0.01)$ & $(0.06)$ & $(0.05)$ & $(0.04)$ \\
WI & -0.03 & -0.19 & 0.12 & 0.24 & - & 0.92 & -0.36 & -0.15 & 0.06 \\
& & & & & & $(0.02)$ & $(0.08)$ & $(0.07)$ & $(0.08)$ \\
PL & -0.44 & -0.48 & 0.59 & 0.66 & 0.61 & - & -0.56 & -0.48 & 0.50 \\
& & & & & & & $(0.06)$ & $(0.05)$ & $(0.06)$ \\
BR & 0.34 & 0.33 & -0.25 & -0.25 & -0.08 & -0.24 & - & 0.76 & -0.56 \\
DI & 0.45 & 0.37 & -0.54 & -0.51 & 0.08 & -0.28 & 0.21 & - & -0.49 \\
& & & & & & & & & $(0.05)$ \\
ST & -0.66 & -0.55 & 0.78 & 0.56 & -0.22 & 0.22 & -0.17 & -0.44 & - \\
\hline
\end{tabular}

$\mathrm{VO}=$ best time in voltstart, $\mathrm{AU}=$ best time in autostart, $\mathrm{EA}=(\text { total earnings })^{1 / 4}, \mathrm{ES}=(\mathrm{earnings} / \mathrm{start})^{1 / 4}$, WI=logit $(\mathrm{number}$ of first placings), $\mathrm{PL}=\operatorname{logit}$ (number of first to third placings), BR=logit (number of races breaking stride), DI=logit (number of disqualified races), ST=number of starts

proved by using records from several age classes, especially for other than time traits. Saastamoinen and Ojala (1991) reported repeatabilities of equal magnitude over the first three age classes. Similar phenotypic correlations for the same traits among different age groups, which can be interpreted as repeatabilities from one age group to another, have also been reported (e.g., Pylvänäinen 1987, Arnason 1989, Pösö 1993).

\section{Correlations}

The genetic correlations among the performance traits for Finnhorse and Standardbred trotters were all of high magnitude and favourable considering the breeding goals (Tables 3 and 4). The highest genetic correlations were found between time and money traits implying that, in fact, these measurements monitor the same trait genetical- ly. Differences between the two breeds were small, although for Finnhorse trotters the associations between number of starts and other measurements were slightly higher than for Standardbred trotters, whereas for Standardbred trotters the correlations between first placings and other performance traits were somewhat higher than for Finnhorse trotters.

The phenotypic correlations were generally of equal sign to the genetic ones but considerably lower, especially those between first placings and other traits. The low negative phenotypic correlation, for instance, between first placings and best time in voltstart compared to the high negative genetic correlation is a result from a small positive residual correlation (0.06). This positive, i.e., unfavourable correlation is probably explained by the fact that faster horses will move on to race against better horses which makes winning more difficult. Moreover, the 
Pösö, J. \& Ojala, M. Estimates of genetic parameters of trotting performance traits

Table 4. Estimates of genetic (above diagonal) and phenotypic (below diagonal) correlations, and standard errors for the genetic correlations (in parentheses) of performance traits for Standardbred trotters.

\begin{tabular}{|c|c|c|c|c|c|c|c|c|c|}
\hline Trait & vo & $\mathrm{AU}$ & EA & ES & WI & PL & BR & DI & ST \\
\hline VO & - & $\begin{array}{c}0.98 \\
(0.00)\end{array}$ & $\begin{array}{l}-0.94 \\
(0.01)\end{array}$ & $\begin{array}{l}-0.96 \\
(0.01)\end{array}$ & $\begin{array}{l}-0.72 \\
(0.06)\end{array}$ & $\begin{array}{l}-0.82 \\
(0.03)\end{array}$ & $\begin{array}{c}0.67 \\
(0.04)\end{array}$ & $\begin{array}{c}0.69 \\
(0.04)\end{array}$ & $\begin{array}{l}-0.64 \\
(0.05)\end{array}$ \\
\hline $\mathrm{AU}$ & 0.81 & - & $\begin{array}{l}-0.93 \\
(0.01)\end{array}$ & $\begin{array}{l}-0.95 \\
(0.01)\end{array}$ & $\begin{array}{l}-0.75 \\
(0.05)\end{array}$ & $\begin{array}{l}-0.83 \\
(0.03)\end{array}$ & $\begin{array}{c}0.63 \\
(0.05)\end{array}$ & $\begin{array}{c}0.69 \\
(0.05)\end{array}$ & $\begin{array}{l}-0.61 \\
(0.05)\end{array}$ \\
\hline EA & -0.80 & -0.76 & - & $\begin{array}{c}099 \\
(0.00)\end{array}$ & $\begin{array}{c}0.76 \\
(0.05)\end{array}$ & $\begin{array}{c}092 \\
(0.02)\end{array}$ & $\begin{array}{l}-0.66 \\
(0.05)\end{array}$ & $\begin{array}{l}-0.69 \\
(0.05)\end{array}$ & $\begin{array}{c}0.76 \\
(0.04)\end{array}$ \\
\hline ES & -0.75 & -0.71 & 094 & - & $\begin{array}{c}0.83 \\
(0.04)\end{array}$ & $\begin{array}{c}095 \\
(0.01)\end{array}$ & $\begin{array}{l}-0.66 \\
(0.04)\end{array}$ & $\begin{array}{l}-0.71 \\
(0.04)\end{array}$ & $\begin{array}{c}0.65 \\
(0.05)\end{array}$ \\
\hline WI & -0.06 & -0.15 & 0.15 & 0.28 & - & $\begin{array}{c}093 \\
(0.02)\end{array}$ & $\begin{array}{c}-0.44 \\
(0.08)\end{array}$ & $\begin{array}{l}-0.44 \\
(0.09)\end{array}$ & $\begin{array}{c}0.25 \\
(0.10)\end{array}$ \\
\hline PL & -0.42 & -0.45 & 0.60 & 0.68 & 0.61 & - & $\begin{array}{l}-0.60 \\
(0.06)\end{array}$ & $\begin{array}{l}-0.62 \\
(0.06)\end{array}$ & $\begin{array}{c}0.52 \\
(0.07)\end{array}$ \\
\hline BR & 0.44 & 0.42 & -0.44 & -0.42 & -0.02 & -0.28 & - & $\begin{array}{c}0.89 \\
(0.04)\end{array}$ & $\begin{array}{l}-0.42 \\
(0.08)\end{array}$ \\
\hline DI & 0.52 & 0.47 & -0.59 & -0.54 & 0.07 & -0.29 & 0.41 & - & $\begin{array}{l}-0.45 \\
(0.08)\end{array}$ \\
\hline ST & -0.62 & -0.56 & 0.75 & 051 & -0.22 & 022 & -0.32 & -0.49 & - \\
\hline
\end{tabular}

$\mathrm{VO}=$ best time in voltstart, $\mathrm{AU}=$ best time in autostart, $\mathrm{EA}=(\text { total earnings })^{1 / 4}, \mathrm{ES}=(\text { earnings/start })^{1 / 4}$, WI=logit $(\mathrm{number}$ of first placings), $\mathrm{PL}=$ logit (number of first to third placings), $\mathrm{BR}=$ logit (number of races breaking stride), DI=logit (number of disqualified races), ST=number of starts

residual correlation between first placings and earnings was only slightly favourable implying that even though it is difficult to win in superior races the prize money in these races is bigger.

Correlations among trotting performance traits estimated from repeated annual records are not given in the literature. Studies in which genetic correlations have been estimated from career results are somewhat more numerous. When annual records were pooled up to the age of 7 years for Finnhorse trotters and up to the age of 6 years for Standardbred trotters to form career records (Pösö 1993) genetic correlations were close to those found here with one exception. For Standardbred trotters the genetic correlations between first placings and time and money traits were higher than \pm 0.90 , whereas in this study they were distinctly lower. Analysing career records that included annual records for 4- to 6year old Finnhorses and 3- to 5-year old Stand- ardbred trotters, Saastamoinen and Ojala (1991) found very similar phenotypic correlations to those reported here. Using almost the same data, Saastamoinen and Nylander (1996) later reported slightly lower genetic correlations between best time and earnings but similar correlations between number of starts and earnings, and number of starts and best time.

Arnason et al. (1989), however, found somewhat different genetic correlations among performance traits for the North Swedish trotter, a heavier 'cold-blooded' breed like the Finnhorse. In contrast to the present study the association between earnings per start and number of starts was very low and even negative, and the correlation between number of starts and best racing time was only moderate and positive. Moreover, the genetic correlation between total earnings and earnings per start was only 0.40 (compared to 0.99 in this study). In their study Arnason et 
Vol. 6 (1997): 11-18.

al. (1989) found a heritability estimate for number of starts as high as 0.45 ; the authors stated that both the heritability estimate for and the correlations of number of starts were probably biased upwards due to environmental covariance with progeny groups. The breeding goal of North Swedish trotters is not as strictly linked to improved trotting performance as is that of Standardbred trotters because North Swedish trotters are used for other purposes besides racing. Moreover, the prize money in cold-blooded horse races is smaller than for Standardbred trotters, which means that bigger total earnings depend on the number of starts. However, the minor differences between the two breeds in estimates of correlations in this study, and the high correlations between number of starts and other performance traits suggest that the situation for Finnhorse trotters is somewhat different from that for North Swedish trotters. For Finnhorse trotters, as well as for Standardbred trotters, number of starts seems to relate to trotting performance equally to, say, best racing time or earnings, i.e., horses that perform well in races are allowed to race more frequently. Owners and trainers may be unwilling to race a horse that has not performed well in earlier races. Moreover, because races have a limited entry (maximum of 12 or 16 horses per race), inferior horses are more likely to be discarded.

The high genetic correlations among performance traits raise the question as to which traits should be included in the total merit index. To best accommodate the diversity of per- formance traits, it would appear logical to include the traits among which the genetic correlations are lowest, and which may therefore monitor trotting performance from different aspects. The traits currently used in the sire breeding value estimation system in Finland include best time in voltstart, transformations of earnings per start, number of first placings, and first to third placings, number of disqualified races, and frequency of raced progeny relative to all progeny for a sire. Separate indices of different traits and the total merit indices are published annually (Peltonen 1996). Judging by the very high estimates of correlation among the present traits, some of them could be either left out or replaced by some other trait.

Yet another possible approach for estimating breeding values could be to use individual racing records. The horses in each single race would then be compared with each other, as happens in practice, by including a factor common to all horses in the same race in the statistical model. This approach could reduce the number of considered traits. Even though racing time in each race itself is irrelevant, it would give not only the order among the horses in the race but also information on distances between the horses within races. A study on this approach, together with revision of the present system for estimating breeding values in Finland, is underway.

Acknowledgements. The authors wish to thank the Finnish Trotting and Breeding Association for kindly providing the data, and Veijo Vilva for technical assistance.

\section{References}

Arnason, Th., Bendroth, M., Philipsson, J., Hendriksson, K. \& Darenius, A. 1989. Genetic evaluation of Swedish trotters. In: Langlois, B. (ed.). State of breeding evaluation in trotters. EAAP Publications. No. 42, Wageningen Pers, Wageningen. p.106-130.

Jensen, J. \& Madsen, P. 1994. A user's guide to DMU, a package for analyzing multivariate mixed models. National Institute of Animal Science, Tjele, Denmark. Mimeo. 19 p. Johnson, D.L. \& Thompson, R. 1995. Restricted Maximum Likelihood estimation of variance components for univariate animal models using sparse matrix techniques and average information. Journal of Dairy Science 78: 449-456.

Langlois, B. 1984. Héritabilité et corrélations génétiques des temps record et des gains établis par les trotteurs Francais de 2 à 6 ans. 35th Annual Meeting of European Association of Animal Production, Prague, Czech Republic. 12 p. (Mimeograph).

Peltonen, T. 1996. Uudet oriit voivat muuttaa jărjestyksen. Hevosurheilu 20B: 86-89. (in Finnish). 


\title{
AGRICULTURAL AND FOOD SCIENCE IN FINLAND
}

\section{Pösö, J. \& Ojala, M. Estimates of genetic parameters of trotting performance traits}

Pösō, J. 1993. Ravikilpailumenestystä kuvaavien mittojen periytyvyys ja niiden väliset yhteydet kilpailu-uran eri vaiheissa. University of Helsinki, Department of Animal Science Publications No 3, Helsinki. 61 p. (M.Sc.Thesis).

- , Ojala, M. \& Vilva, V. 1994. Heritability estimates of trotting performance traits for early career and annual records. Proceedings of 5th World Congress on Genetics of Applied Livestock Production. Guelph, Canada. 17: 471-474.

Pylvănăinen. H. 1987. Ravikilpailuominaisuuksien perinnölliset tunnusluvut eri ikăvuosina ja ikăvuosien vălillä. University of Helsinki, Department of Animal Breeding Publications No 75. 87 p. (M.Sc. Thesis).

Saastamoinen, M.T. \& Nylander, A. 1996. Genetic and phenotypic parameters for age at starting to race and racing performance during early career in trotters.
Livestock Production Science 45: 63-68.

Saastamoinen, M.T. \& Ojala, M.J. 1991. Estimates of genetic and phenotypic parameters for racing performance in young trotters. Acta Agriculturae Scandinavica 41: 427-436.

- \& Ojala, M. 1994. Influence of different combinations of racing years on early career performance in trotters. Acta Agriculturae Scandinavica, Section A, Animal Science 44: 208-213.

Snedecor, G.W. \& Cochran, W.G. 1967. Statistical methods. The lowa State University Press, Ames, lowa. $598 \mathrm{p}$.

Tavernier, A. 1989. Breeding evaluation of French trotters according to their race earnings. 2. Prospects. In: Langlois, B. (ed.). State of breeding evaluation in trotters. EAAP Publications No. 42, Wageningen Pers, Wageningen. p. 41-54.

\section{SELOSTUS}

\section{Ravihevosten jalostettavia ominaisuuksia kuvaavien kilpailumittojen perinnölliset tunnusluvut}

\author{
Jukka Pösö ja Matti Ojala \\ Maatalouden tutkimuskeskus ja Helsingin yliopisto
}

Tutkimuksessa arvioitiin ravihevosten jalostettavia ominaisuuksia kuvaavien ravikilpailuista saatavien mittojen periytyvyyttä ja toistuvuutta, sekä mittojen välisiä perinnöllisiä ja fenotyyppisiä yhteyksiä. Tutkittavia ravihevosten vuosittaista menestymistä kuvaavia mittoja eli kilpailumittoja olivat paras aika voltti- ja autolähetyksellä sekä matemaattiset muunnokset kokonaisvoittosummasta, lähtöä kohti lasketusta voittosummasta, voittojen, sijoittumisten, hylkäysten, laukkojen ja lähtöjen lukumäärästä. Tutkimusaineistona oli 6934 suomenhevosen ja 5298 lämminverisen ravihevosen vuosittaiset kilpailutulokset neljältä eri ikäkaudelta. Ominaisuuksien perinnöllisten tunnuslukujen laskemiseen tarvittavat varianssikomponentit arvioitiin REML-menetelmällä (restricted maximum likelihood) ottamalla huomioon hevosen syntymävuosi, sukupuoli ja ikä kilpailuvuonna sekä kaikki hevosten väliset tunnetut sukulaisuussuhteet.
Korkeimmat periytymisasteen arviot saatiin parhaalle ajalle $(0,29-0,35)$, myös voittosummaan perustuvien mittojen periytyvyys oli kohtalainen. Vähiten eläinten välistä perinnöllistä vaihtelua havaittiin kilpailujen lukumäärässä. Vuoden parhaan kilpailuajan toistuvuus oli korkea, mutta muiden kilpailumittojen toistuvuuksien arviot olivat vain kohtalaisia. Tämän johdosta voidaan päätellä, että ottamalla huomioon usean ikäluokan vuosittaiset kilpailutulokset, voidaan ravihevosten jalostusarvostelujen luotettavuutta parantaa. Kilpailumenestystä kuvaavien mittojen väliset perinnölliset yhteydet olivat yleensä erittäin voimakkaita ja samansuuntaisia jalostustavoitteiden kanssa. Tämän tutkimuksen perusteella aika- ja rahamittojen voidaankin sanoa kuvaavan perinnöllisesti lähes samaa ominaisuutta. 